\title{
Effect of Partial Replacement of Sand with Limestone Filler on Some Properties of Normal Concrete
}

\author{
Rana Burhan Abdurrahman Alshahwany \\ assistant lecturer \\ Civil Engg. Dept. / Mosul Univ.
}

\begin{abstract}
In recent years, there is a growing interest in the use of crushed sand obtained from limestone quarries in some countries where river sand is not widely available. Besides, the demand for aggregates to produce concrete is still high while natural resources decrease. The fines content in limestone is usually high (particles with a size of 0.15-0.7 mm) which can affect concrete properties in an either positive or negative way. Studies on aggregate containing fine materials are vitally important. However, little work has been done so far on the effect of fines in crushed sand on the properties of concrete.

This paper examines the influence of limestone filler in sand on concrete properties, which include workability of fresh concrete (slump test method), compressive and tensile strength, unit weight, and ultrasonic pulse velocity. Six concrete mixtures containing different ratios of limestone filler $(0,10,20,30,40,50) \%$ sand replacement were used while maintaining a constant water/cement ratio. The results proved that limestone filler replacing sand up to $20 \%$ without adversely affecting concrete strength.
\end{abstract}

Key words: limestone filler; crushed sand.

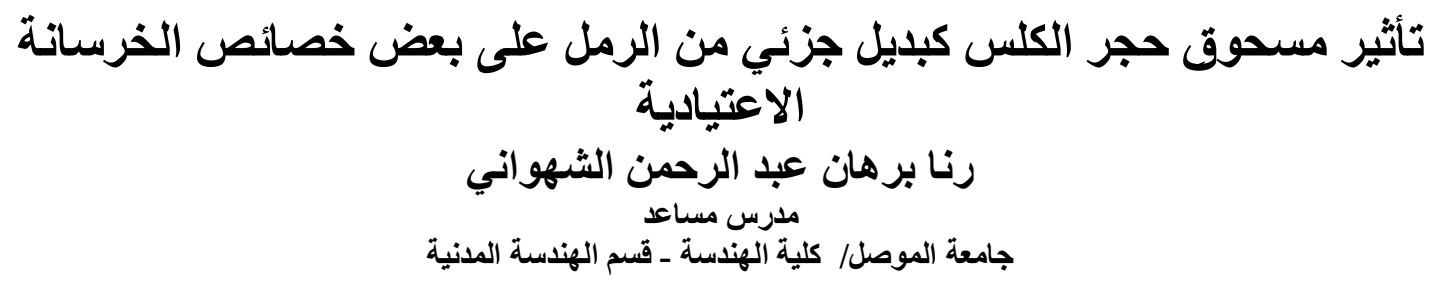

\section{الخلاصة}

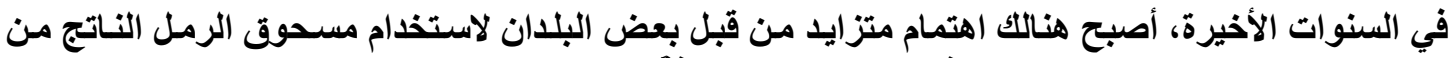

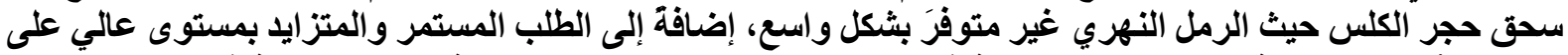

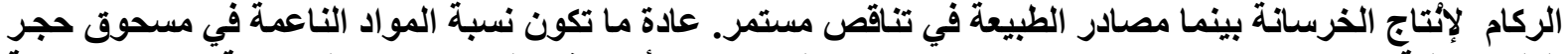

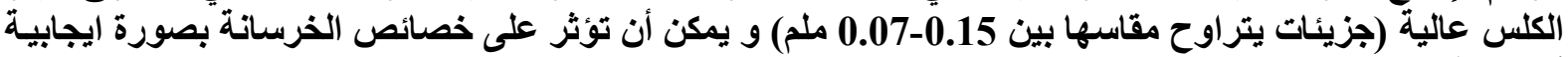

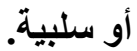

يمكن القول ان الدراسات حول الركام الحاوي على مواد ناعمة إجمالاً مهمة بشكل حيوي ومع ذلك فالقليل من

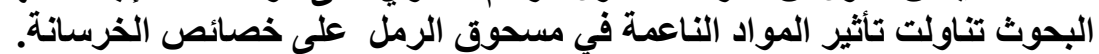

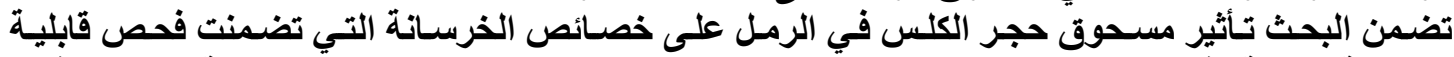

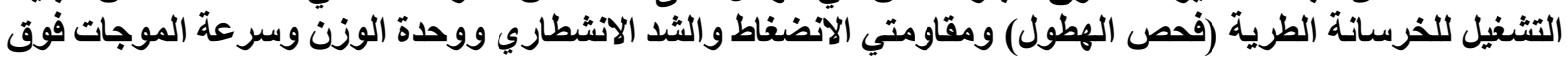

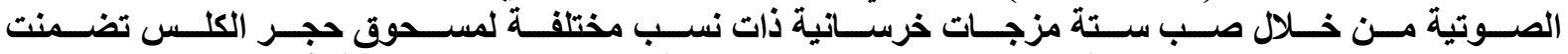

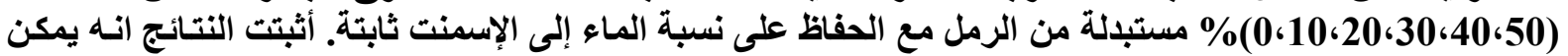

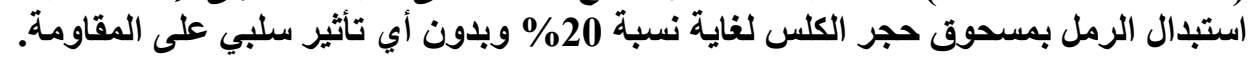




\title{
Introduction
}

In recent years, there is a growing interest in the use of crushed sand obtained from limestone quarries in some countries where river sand is not widely available. Besides, the demand for aggregates to produce concrete is still high while natural resources decrease.

A large amount of material in the size of filler is produced during the course of crushing the weak limestone, in particular, which may well be used as an aggregate. The application of these materials is beneficial to improving the concrete so as to decrease air voids [1].

For many years limestone has been increasingly used in concrete as a coarse aggregate, filler or as a main cement constituent [2]. It is applied in high performance concrete as well as in normal or low performance concrete [3,4,5]. Compared to plain concrete with the same w/c ratio and cement type, concrete with a high limestone filler content with suitable particle size distribution (PSD) possesses generally improved strength characteristics.

A certain amount of fines is helpful in concrete for improving cohesiveness and preventing bleeding. However, excessive quantities of fines tend to increase the water demand and tend to impair the aggregate-cement paste bond. Crushed rock acts as filler and helps to reduce the total voids content in concrete. Consequently, this contributes to improve the quality of concrete. Limestone crusher dust is used as a filler material for cement or aggregates and might have some beneficial effects on concrete depending on the percentage replacement and chemical composition of dust [6].

The effect of inclusion of limestone filler in cement on fresh and hardened mortar and concrete has been a major research topic for many years [2], but little work has been done so far on the effect of limestone filler in sand on the properties of concrete. This paper reports the results of an experimental investigation on the influence of limestone filler as partial replacement of sand on concrete properties.

\begin{abstract}
Aim of study
Crushed limestone is used as a coarse aggregate or a filler material for cement and aggregates, it might have some beneficial effects on concrete depending on the percentage replacement, so the objective of the investigation subject of this paper is to study quality criteria of concrete made of sand with partial replacement of limestone filler with locally available material. To find out the extent of improvement in concrete properties for different amounts of limestone filler, proportion of $(0,10,20,30,40,50) \%$ replacement are considered, concrete properties include workability (slump test) of fresh concrete, unit weight, ultrasonic pulse velocity, compressive and splitting tensile strength of hardened concrete are studied.
\end{abstract}

\section{Experimental details Materials \\ Cement}

The cement used in this study was obtained from Senjar Cement Plant. The chemical compositions and physical properties, of the cement used, were determined according to Iraqi Standard (IQS 5 - 1984)[7] are given in Table(1).

\section{Limestone filler}

Crushed limestone filler retained on the sieve No. 200 was used with specific gravity of 2.61. The chemical compositions was determined and presented in Table (2). 
Alshahwany: Effect of Partial Replacement of Sand with Limestone Filler

Table(1): Properties of cement

Chemical analysis of cement*

\begin{tabular}{|c|c|c|c|c|c|c|c|c|}
\hline Oxide composition & $\mathrm{SiO}_{2}$ & \multicolumn{2}{|c|}{$\mathrm{Fe}_{2} \mathrm{O}_{3}$} & $\mathrm{Al}_{2} \mathrm{O3}$ & \multicolumn{2}{|c|}{$\mathrm{CaO}$} & MgO & $\mathrm{SO}_{3}$ \\
\hline Content $(\%)$ & 21.50 & \multicolumn{2}{|c|}{2.68} & 6.2 & \multicolumn{2}{|c|}{62.76} & 2.80 & 2.27 \\
\hline $\begin{array}{l}\text { IQS No5-1984 } \\
\text { requirements(\%) }\end{array}$ & $17-25$ & \multicolumn{2}{|c|}{$0.5-6.0$} & $3-8$ & \multicolumn{2}{|c|}{$60-67$} & Max 5 & $\operatorname{Max} 2.8$ \\
\hline \multicolumn{2}{|c|}{ Mineralogical components } & \multicolumn{2}{|c|}{ C3S } & \multicolumn{2}{|c|}{$\mathrm{C} 2 \mathrm{~S}$} & \multicolumn{2}{|c|}{ C3A } & C4AF \\
\hline \multicolumn{2}{|c|}{ Content $(\%)$} & \multicolumn{2}{|c|}{40.93} & \multicolumn{2}{|c|}{28.78} & \multicolumn{2}{|c|}{12.06} & 7.89 \\
\hline \multicolumn{2}{|l|}{$\begin{array}{c}\text { IQS No5-1984 } \\
\text { requirements }(\%)\end{array}$} & \multicolumn{2}{|c|}{$31.3-41.05$} & \multicolumn{2}{|c|}{$28.61-37.9$} & \multicolumn{2}{|c|}{$11.96-12.3$} & $7.72-8.02$ \\
\hline \multicolumn{9}{|l|}{ Mechanical properties } \\
\hline \multirow[t]{2}{*}{ Age (days) } & \multicolumn{4}{|c|}{ Compressive strength (MPa) } & \multicolumn{4}{|c|}{ Tensile strength $(\mathrm{MPa})$} \\
\hline & \multicolumn{2}{|c|}{\begin{tabular}{l|l} 
Cement used &
\end{tabular}} & \multicolumn{2}{|c|}{$\begin{array}{l}\text { IQS No5-1984 } \\
\text { requirements }\end{array}$} & \multicolumn{3}{|c|}{\begin{tabular}{c|l} 
Cement & \\
used &
\end{tabular}} & $\begin{array}{l}\text { IQS No5-1984 } \\
\text { requirements }\end{array}$ \\
\hline 3 & \multicolumn{2}{|c|}{19.2} & \multicolumn{2}{|c|}{ Iot less than 16} & \multicolumn{3}{|c|}{1.72} & Not less than 1.6 \\
\hline 7 & \multicolumn{2}{|c|}{26.1} & Jot le & $\operatorname{ann} 24$ & & 2.55 & & Not less than 2.4 \\
\hline Physical properties & & & & & & & & \\
\hline Setting time (hrs) & & & nitial & & & & & Final \\
\hline & Cem & t used & & $\begin{array}{l}\text { To5-19 } \\
\text { remen }\end{array}$ & & Cem & used & $\begin{array}{c}\text { IQS No5-1984 } \\
\text { requirements }\end{array}$ \\
\hline & & & & $\begin{array}{l}\text { s than } \\
\text { min }\end{array}$ & & & & $\begin{array}{c}\text { Not more than } 10 \\
\text { hrs }\end{array}$ \\
\hline
\end{tabular}

* Data are given by the manufacturer.

Table (2): Chemical analysis of limestone filler*

\begin{tabular}{|c|c|c|c|c|c|c|c|}
\hline Oxide Composition & $\mathbf{S i O}_{\mathbf{2}}$ & $\mathbf{F e}_{\mathbf{2}} \mathbf{O}_{\mathbf{3}}$ & $\mathbf{A l}_{\mathbf{2}} \mathbf{O 3}$ & $\mathbf{C a O}$ & $\mathbf{M g O}$ & $\mathbf{S O}_{3}$ & Losses \\
\hline Content (\%) & 1.81 & 0.27 & 0.27 & 50.28 & 1.53 & 0.25 & 45.59 \\
\hline
\end{tabular}

* Analysis done in Badush Cement Plant.

\section{Aggregate}

\section{Coarse aggregate}

River rounded gravel comply with the (B.S 882:1992)[8] was used as a coarse aggregate with max aggregate size $12.5 \mathrm{~mm}$, Fig.(1) shows particle size distribution of coarse aggregate.

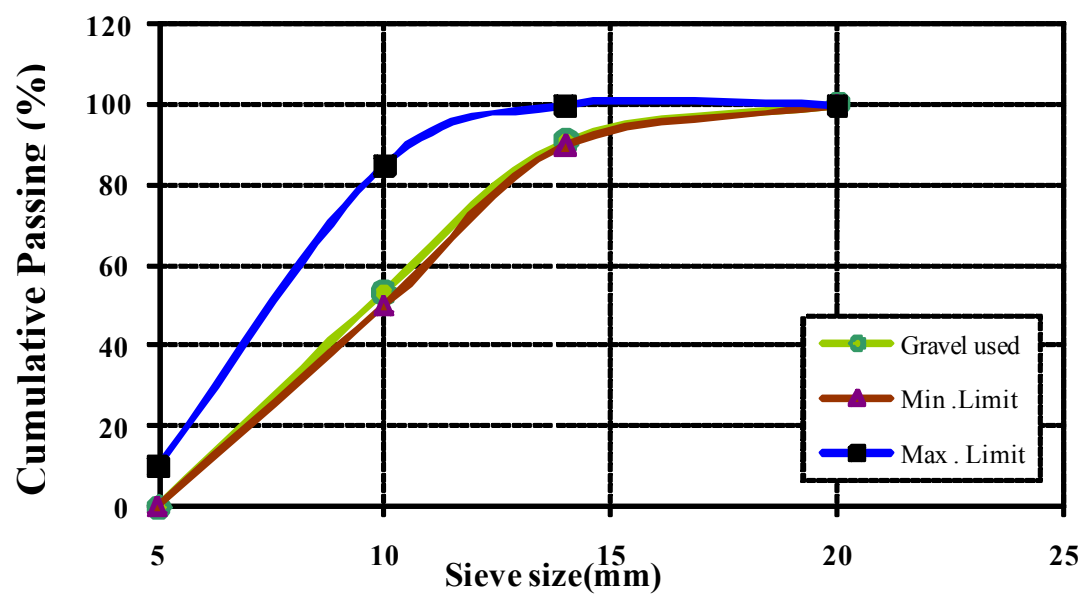

Fig.(1): Particle size distribution of coarse aggregate 


\section{Fine aggregate}

River sand was used as fine aggregate with fineness modulus of 2.81, the results of the sieve analysis that was carried out in accordance with the (B.S. 882:1992)[8] for the fine aggregate for sand with partial replacement of limestone filler content include $(0,10,20,30$, $40,50) \%$ showed that its grading fits within the limits set out in B.S. 882 , Fig. (2) shows the particle size distribution of fine aggregate (sand with percentage partial replacement of limestone filler).

Fineness modulus decrease with limestone filler amount from 2.81 (for the reference mix) down to 2.11 (for $50 \%$ limestone filler content) which represent about $25 \%$ decrease (Table (3)) despite this, the aggregate remains in conforming with BS standards.

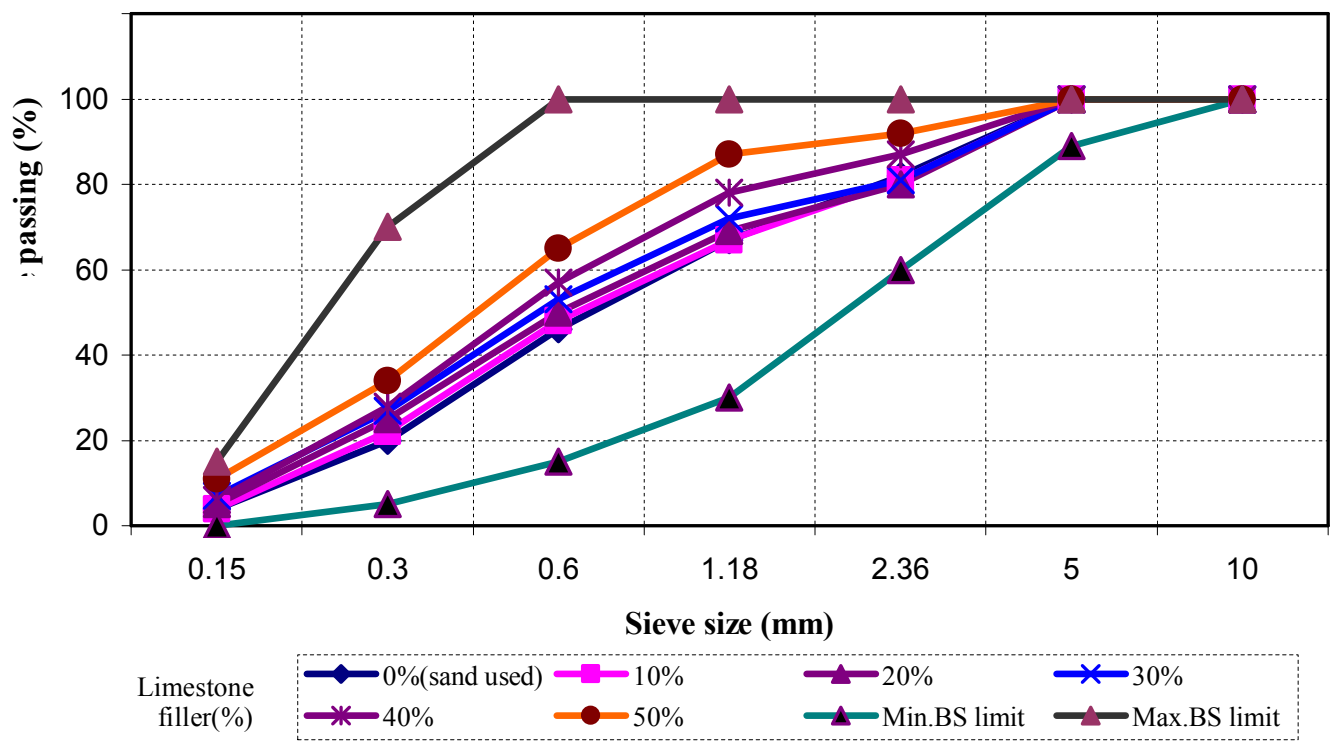

Fig.(2): Particle size distribution of fine aggregate(sand with percentage partial replacement of limestone filler)

\section{Concrete mixes used in investigation}

A total of six concrete mixtures were prepared. The first is a reference concrete mix (control mix), the remaining five mixtures with limestone filler of $(10,20,30,40,50) \%$ sand replacement. Water to cement ratio is constant at 0.57 throughout the test. The details of mixes composition are shown in Table (3).

Table (3): Composition of concrete mixtures

\begin{tabular}{|c|c|c|c|c|c|c|}
\hline \multirow{2}{*}{\begin{tabular}{c}
\multirow{2}{*}{$\begin{array}{c}\text { Filler } \\
(\%)\end{array}$} \\
adition
\end{tabular}} & $\begin{array}{c}\text { Cement } \\
\text { content }\end{array}$ & \multicolumn{2}{|c|}{$\begin{array}{c}\text { Aggregate } \\
\text { content }\end{array}$} & $\begin{array}{c}\text { Limestone } \\
\text { filler content }\end{array}$ & $\begin{array}{c}\text { Water } \\
\text { content }\end{array}$ & $\begin{array}{c}\text { sand with filler } \\
\text { fineness modulus }\end{array}$ \\
\cline { 2 - 5 } & & sand & gravel & & & \\
\hline 0 & 334 & 668 & 1202 & 0 & 190.4 & 2.81 \\
\hline 10 & 334 & 601 & 1202 & 66.8 & 190.4 & 2.78 \\
\hline 20 & 334 & 534 & 1202 & 133.6 & 190.4 & 2.71 \\
\hline 30 & 334 & 468 & 1202 & 200.4 & 190.4 & 2.60 \\
\hline 40 & 334 & 401 & 1202 & 267.2 & 190.4 & 2.44 \\
\hline 50 & 334 & 334 & 1202 & 334 & 190.4 & 2.11 \\
\hline
\end{tabular}




\section{Specimen preparation and testing program}

Aggregate, limestone filler and cement were mixed for one minute in a vertical rotating concrete flow mixer, mixing was continued for a further minute while water was added, slump test was done according to (ASTM C143)[9] to determine the concrete mixtures workability then unit weight test was done according to (ASTM C138)[10].

For each mixture, twelve cubical specimens of $(100 \times 100 \times 100) \mathrm{mm}$ for the compressive strength and three cylindrical specimens of $(100 \phi \times 200) \mathrm{mm}$ for the splitting tensile strength, were cast in steel moulds, a vibration table was used to consolidate the concrete. The specimens prepared were stored under cure conditions until the launch of the experiment.

Compressive strength was determined for 3, 7, 14 and 28 days according to (BS 1881: Part 116)[11]. Splitting tensile test and ultrasonic pulse velocity were determined at 28 days according to (ASTM C496) [12] and (ASTM C 597)[13] respectively .

\section{Results and discussion}

\section{Influence of limestone filler content on the workability of fresh concrete}

The slump test was used to measure workability as a function of limestone filler content for constant $\mathrm{w} / \mathrm{c}$ ratio, the effect of limestone filler content on the slump is shown in Table (4) and Fig.(3) respectively. The slump value seems to decrease with higher percentage of limestone filler content, this result is related to the relatively high water absorption capability which is attributed mainly to the large specific surface of limestone filler [14].

Table (4): Slump values of concrete mixtures

\begin{tabular}{|c|c|c|c|c|c|c|}
\hline Filler addition (\%) & $\mathbf{0}$ & $\mathbf{1 0}$ & $\mathbf{2 0}$ & $\mathbf{3 0}$ & $\mathbf{4 0}$ & $\mathbf{5 0}$ \\
\hline Slump(mm) & 110 & 95 & 75 & 60 & 45 & 30 \\
\hline
\end{tabular}

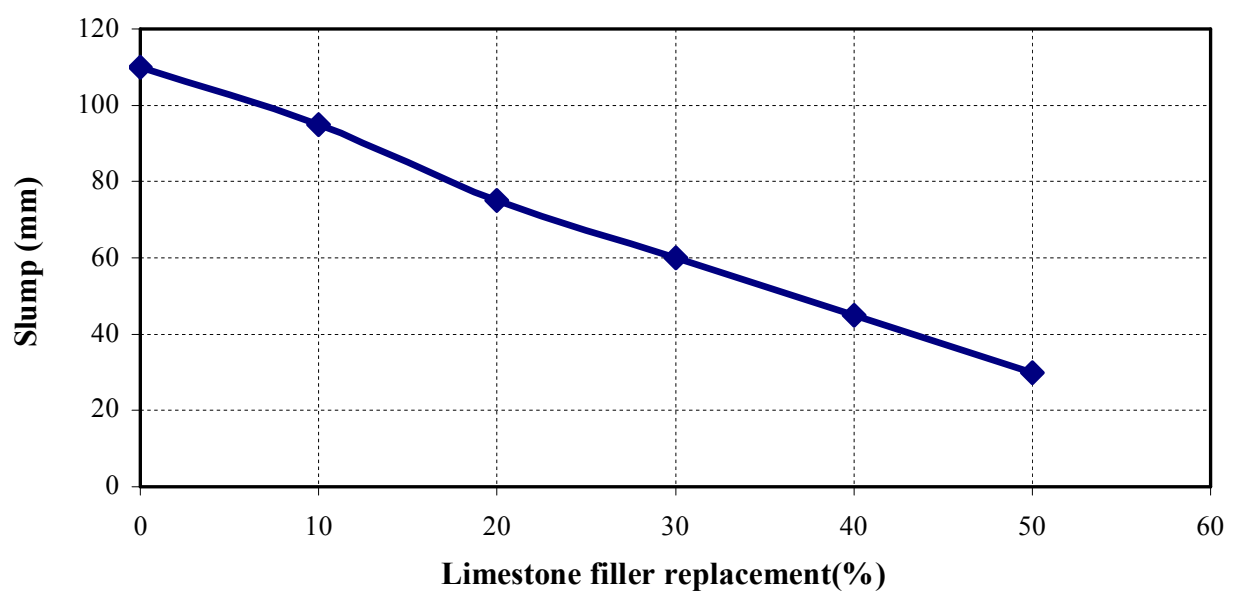

Fig.(3): The effect of percentage limestone filler replacement on the slump

\section{Influence of the limestone filler content on the unit weight}

Average values of three samples for unit weight are given in Table (5) and Fig.(4) respectively for each limestone filler proportion. It was observed that by increasing the limestone filler amount, the unit weight of the mix increases until a certain optimal value of limestone filler amount depending on the sand particle size distribution which represent $20 \%$ of sand replacement with limestone filler, at this amount of limestone filler the unit weight increased by $3.8 \%$ of its reference value, then a regular decrease for higher filler amount but 
still more than the unit weight of control mix; this is interpreted as fine particles of limestone filler filled spaces between grains of sand (before reaching maximum compactness), thereby increasing the mass volume of the mix. Once the voids were completely filled, fine particles then began to occupy the place of sand grains, which decreased the proportion of sand grains, and consequently the unit weight of the mix [15].

Table (5):Unit weight of concrete mixtures

\begin{tabular}{|l|c|c|c|c|c|c|}
\hline Filler addition $\mathbf{( \% )}$ & $\mathbf{0}$ & $\mathbf{1 0}$ & $\mathbf{2 0}$ & $\mathbf{3 0}$ & $\mathbf{4 0}$ & $\mathbf{5 0}$ \\
\hline Unit weight $\left(\mathbf{K g} / \mathbf{m}^{\mathbf{3}}\right)$ & 2473 & 2492 & 2567 & 2533 & 2521 & 2519 \\
\hline
\end{tabular}

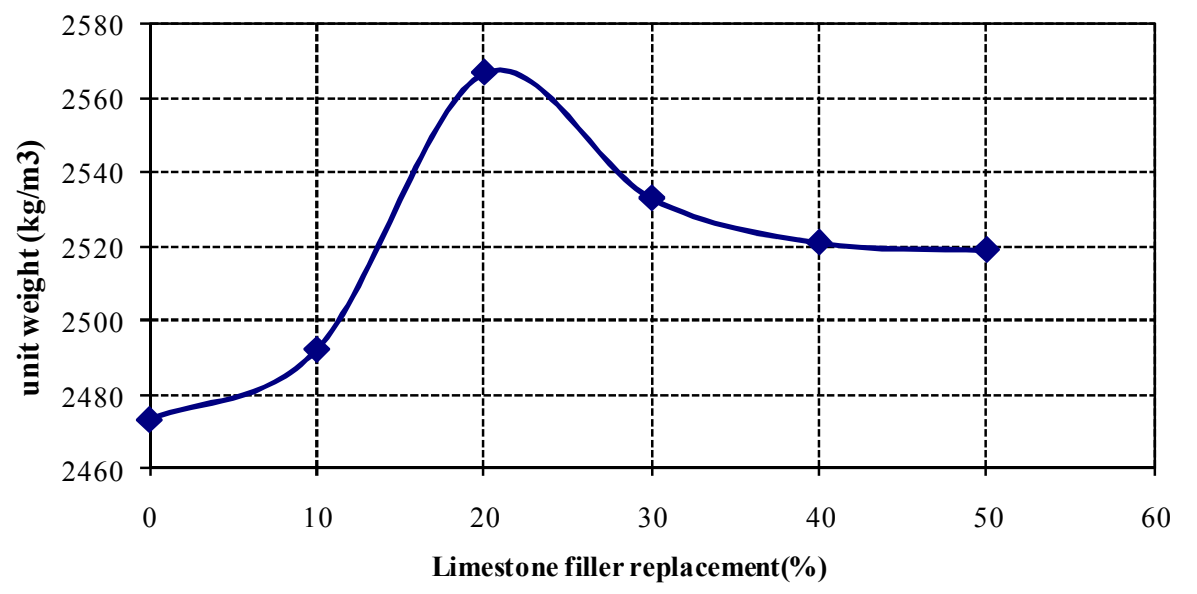

Fig.(4): The effect of percentage limestone filler replacement on the unit weight

\section{Influence of the limestone filler content on the compressive strength}

The compressive strength results of all concrete mixtures at the ages of 3, 7, 14 and 28 days age are illustrated in Table (6) and Fig.(5) respectively. The strength values are the average of three samples. At the different ages, there is a continuing improvement in the strength performance of the mixtures containing $10 \%$ and $20 \%$ limestone filler replacement, the compressive strength decrease when concrete contain $(30,40$ and 50$) \%$ limestone filler replacement with sand comparing to control mix.

Table (6): Compressive strength of concrete mixtures at ages of test days

\begin{tabular}{|c|c|c|c|c|c|c|}
\hline \multirow{2}{*}{ Age (days) } & \multicolumn{6}{|c|}{ Filler addition (\%) } \\
\cline { 2 - 7 } & $\mathbf{0}$ & $\mathbf{1 0 \%}$ & $\mathbf{2 0 \%}$ & $\mathbf{3 0 \%}$ & $\mathbf{4 0 \%}$ & $\mathbf{5 0 \%}$ \\
\hline $\mathbf{3}$ & 15.9 & 16.8 & 18.5 & 15.7 & 15.5 & 15.1 \\
\hline $\mathbf{7}$ & 25.3 & 25.9 & 28.3 & 25.3 & 23.1 & 22.6 \\
\hline $\mathbf{1 4}$ & 28.5 & 30.6 & 32.5 & 28 & 26.8 & 26 \\
\hline $\mathbf{2 8}$ & 33.6 & 35.6 & 38.5 & 33.2 & 31.0 & 30.8 \\
\hline
\end{tabular}




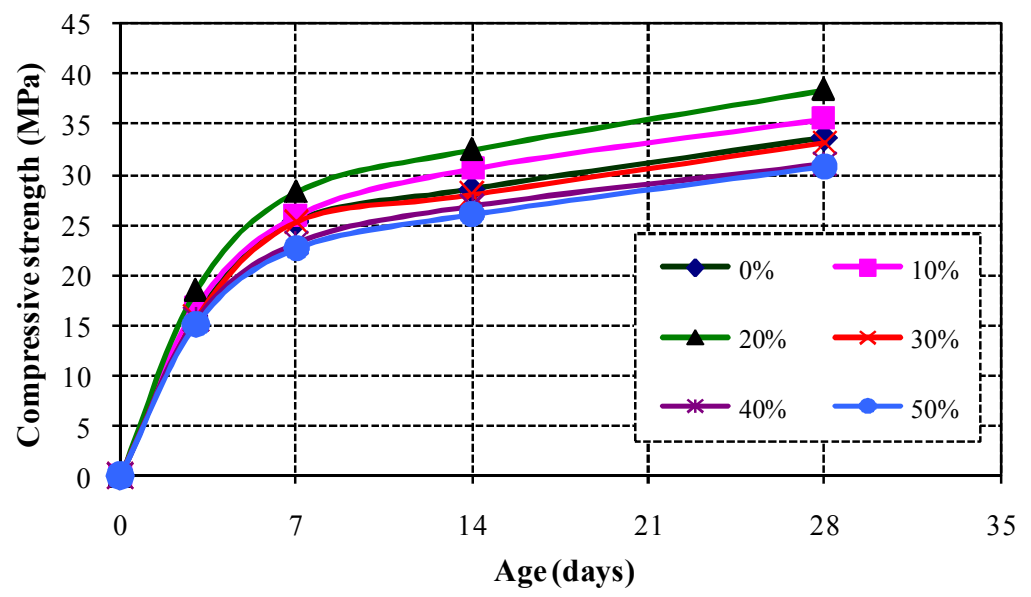

Fig.(5): The effect of percentage limestone filler replacement on the compressive strength at ages of test days

The development of relative compressive strength in concrete mixtures at ages of test days is shown in Fig.(6), relatively little effect of the addition of limestone filler on development of compressive strength of concrete mixtures at ages of test days corresponding to reference mix (without the filler).

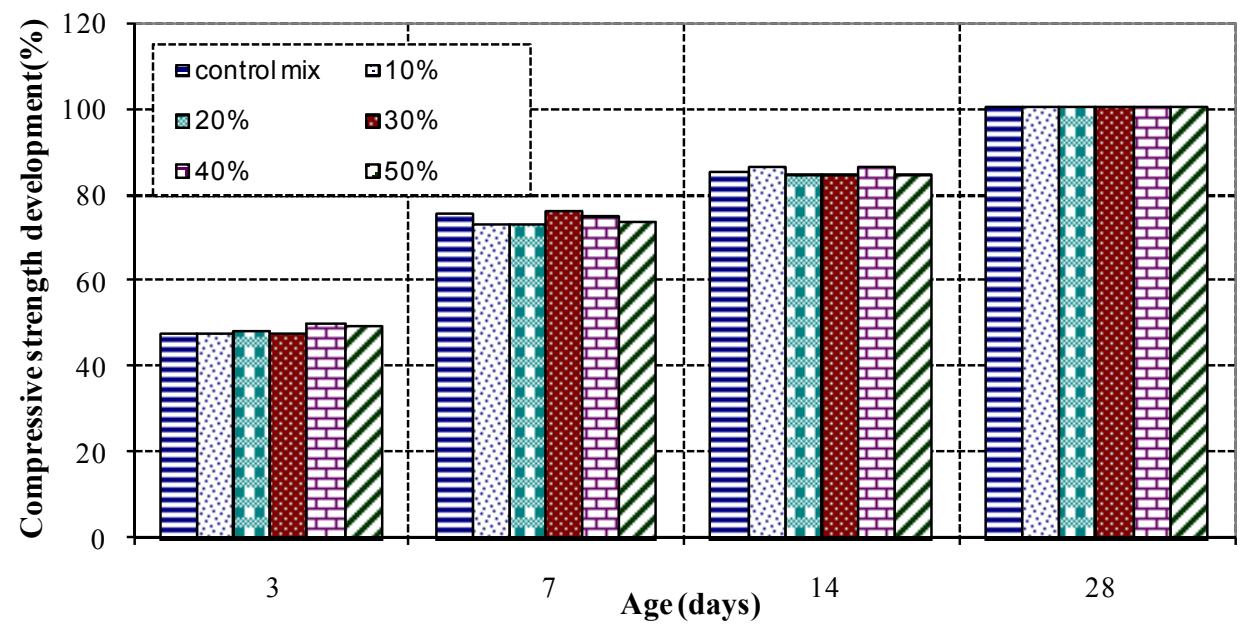

Fig.(6): Development of relative compressive strength in various concrete mixtures at different ages

Average values of three samples for compressive strength at 28 days age are summarized in Fig.(7) as a function of limestone filler proportion, it can be seen that as filler content increases, compressive strength also increases up to an optimal value (in this case at $20 \%$ limestone filler).

To show the effect of the addition of limestone filler on compressive strength of concrete, Fig.(8) shows the compressive strength with different addition of the filler as a percentage of the reference mix (without the filler). 


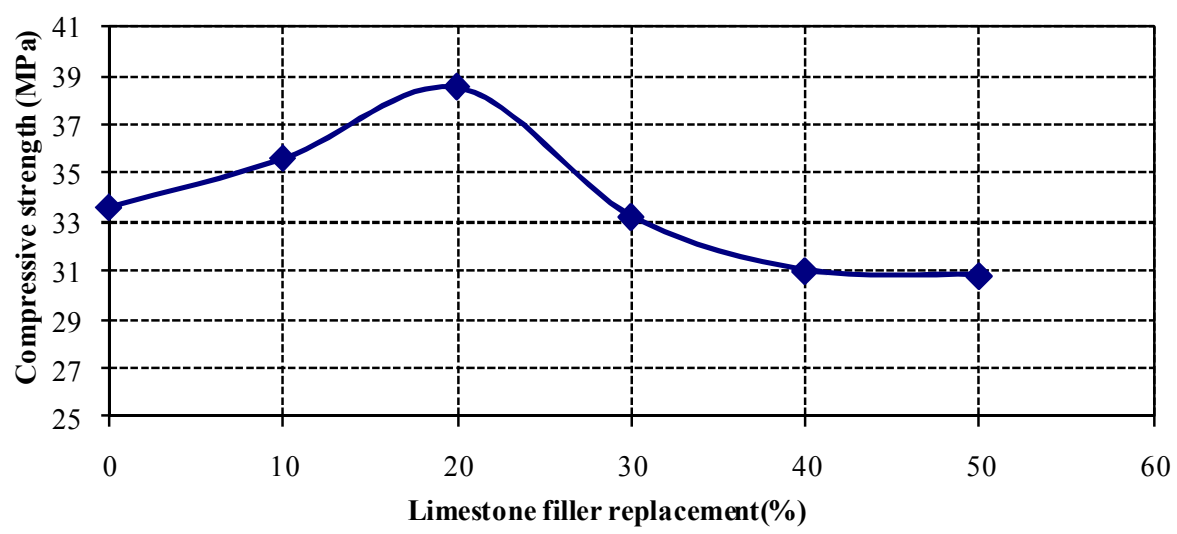

Fig.(7):The influence of percentage limestone filler replacement at 28 days age on the compressive strength

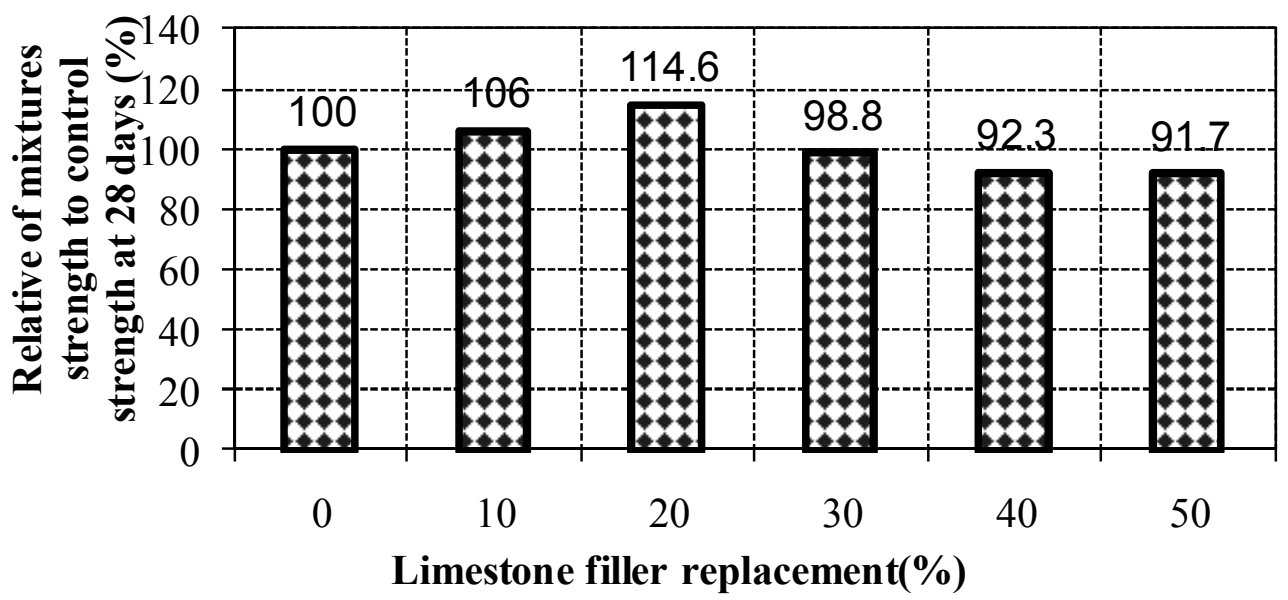

Fig.(8): Relative compressive strength of concrete mixtures to compressive strength of control concrete as a function of limestone filler percentage content

As concluded from Fig.(8) is can be seen that 20\% limestone filler replacement gives the best improvement in compressive strength, The increase is found to be $14.6 \%$ at $20 \%$ replacement level compared to control concrete. Limestone cannot be considered as an inert filler, Pera [16] have studied reactions that occur during the hydration of $\mathrm{C} 3 \mathrm{~S}$ in the presence of calcium carbonate and have proved that, in cement paste, calcium carbonate has an accelerator effect on cement hydration and leads to the formation of carbosilicates and hydrated calcium carboaluminates.

Beyond 20\% limestone filler replacement, compressive strength decreases with the increased filler content, Concrete with $30 \%$ of limestone filler showed a decrease in strength of about $1.2 \%$, the decrease expanded to be $8.3 \%$ at $50 \%$ replacement compared to control mix. Celik observed that [6], beyond an optimal value of crushed stone dust addition, the amount of fines increases so much that the cement paste is not able to coat all fine and coarse particles (i.e. filler as well as sand). This phenomenon weakens the cement-to aggregate bond 
and hence leads to a loss in compressive strength for higher filler amounts than the optimal value.

\section{Influence of the limestone filler content on the splitting tensile strength}

Average values of three samples for splitting tensile strength are summarized in Table(7). Fig.(9) shows the splitting tensile strength as a function of limestone filler proportion, it can be seen that as filler content increases, splitting tensile strength also increases up to an optimal value of $20 \%$ addition, in a similar behavior to that of the compressive strength.

Table (7):Splitting tensile strength of concrete mixtures

\begin{tabular}{|c|c|c|c|c|c|c|}
\hline Filler addition (\%) & $\mathbf{0}$ & $\mathbf{1 0}$ & $\mathbf{2 0}$ & $\mathbf{3 0}$ & $\mathbf{4 0}$ & $\mathbf{5 0}$ \\
\hline Splitting tensile strength (MPa) & 2.5 & 2.8 & 3.2 & 2.5 & 2.4 & 2.3 \\
\hline
\end{tabular}

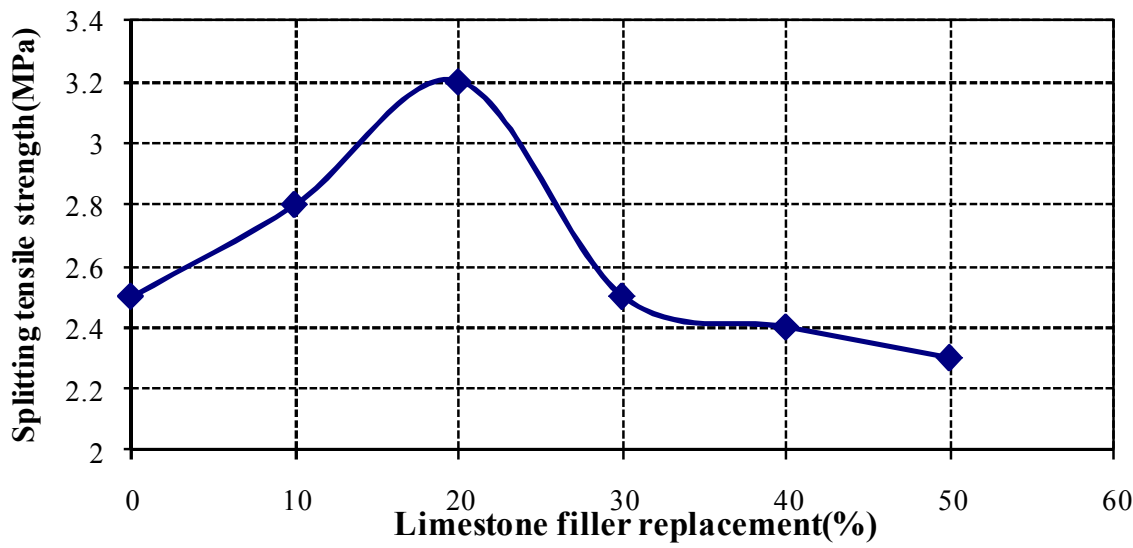

Fig. (9): The influence of percentage limestone filler replacement on the splitting tensile strength

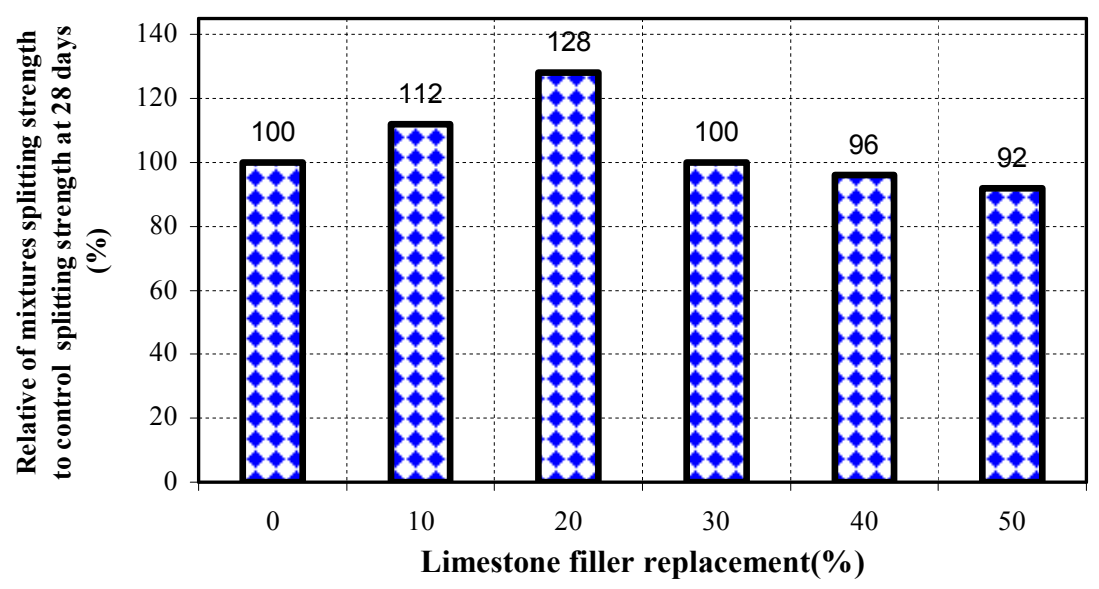

Fig.(10): Relative splitting tensile strength of concrete mixtures to splitting tensile strength of control mixture as a function of limestone filler percentage content 
To compare the splitting tensile strength of concrete mixtures with added limestone filler percentages to that of the control mix, Fig.(10) is plotted. As concluded from Fig.(10) it can be seen that $20 \%$ limestone filler replacement give best improvement in splitting tensile strength, the increase is found to be $28 \%$ at $20 \%$ replacement level compared to control concrete, then splitting tensile strength decrease with the an increase of filler content beyond $20 \%$ replacement, concrete with 50\% limestone filler content showing the highest decrease in splitting tensile strength of about $8 \%$ compared to control mix.

\section{Influence of the limestone filler content on the quality of concrete}

Ultrasonic pulse velocity method is considered one of the non-destructive procedures with more potential to evaluate the quality and the characteristics of concrete. It consists in measuring the transit time of an ultrasonic pulse through the material[17].

The direct ultrasonic pulse velocity values are measured at 28 days on the compressive strength samples having a $10 \mathrm{~cm}$ direct path length using the $55 \mathrm{kHz}$ longitudinal wave transducers placed in direct array. Fig.(11) shows the arrangement used for the ultrasonic pulse velocity measurement.

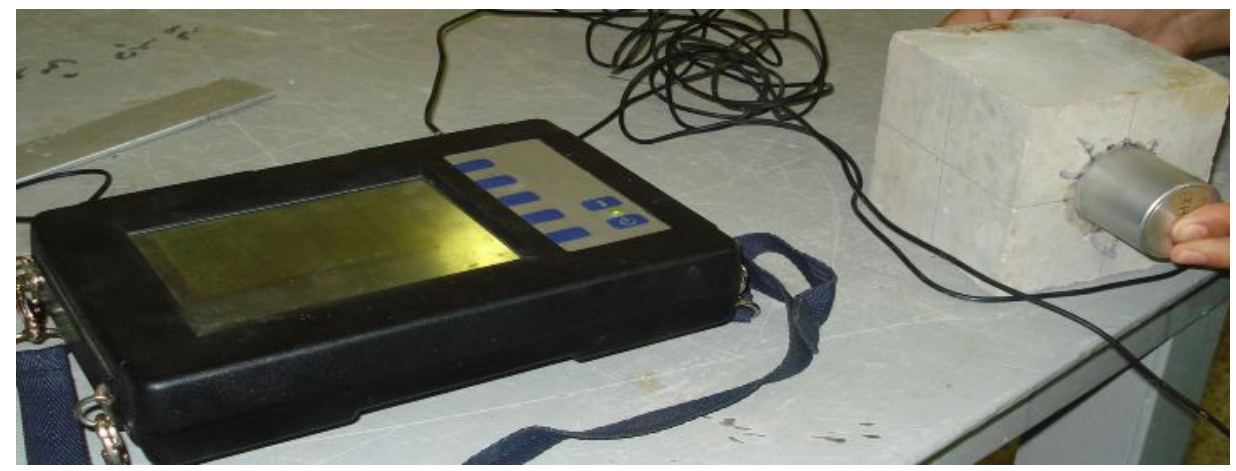

Fig.(11): The arrangement used for the ultrasonic pulse velocity measurement.

Measurements of three samples from each mixture were averaged to obtain the ultrasonic pulse velocity values as shown in Table(8). Fig. (12) displays ultrasonic pulse velocity results as a function of limestone filler replacement. With $10 \%$ and $20 \%$ limestone filler addition, ultrasonic pulse velocity value notably increase then decrease with limestone filler amount increase.

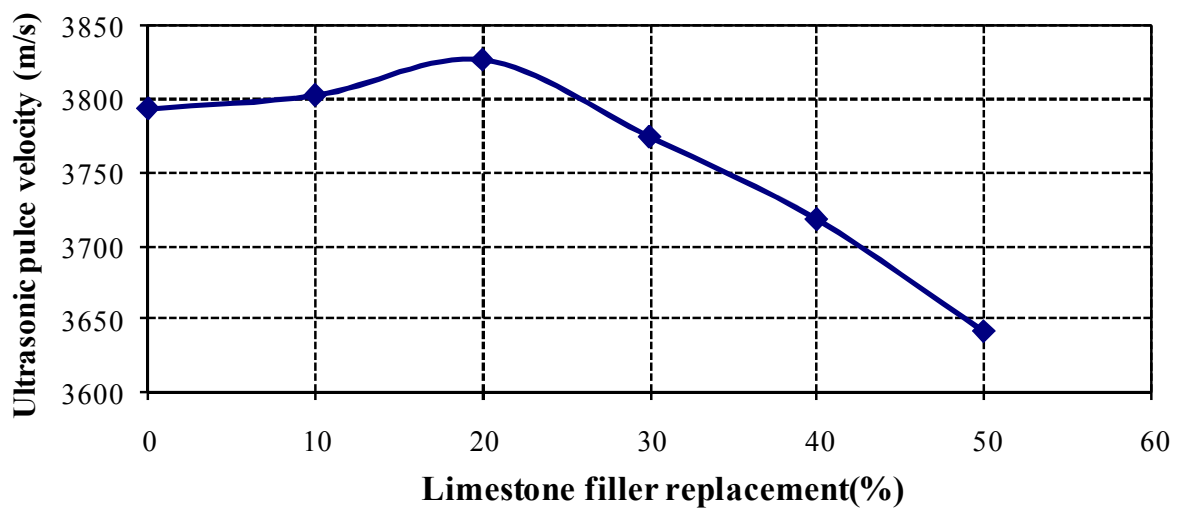

Fig. (12): The influence of percentage limestone filler replacement on the ultrasonic pulse velocity values 
One of the main factors that affect the ultrasonic pulse velocity is the nature of the aggregates as the form and texture, besides, proper graduation of it which affect on the strength of the aggregate-paste interface. [18].

Table (8): Ultrasonic pulse velocity of concrete mixtures

\begin{tabular}{|c|c|c|c|c|c|c|}
\hline Filler addition (\%) & $\mathbf{0}$ & $\mathbf{1 0}$ & $\mathbf{2 0}$ & $\mathbf{3 0}$ & $\mathbf{4 0}$ & $\mathbf{5 0}$ \\
\hline Ultrasonic pulse velocity(m/s) & 3793 & 3802 & 3826 & 3774 & 3717 & 3641 \\
\hline
\end{tabular}

According to the classification criterion for concrete based on ultrasonic pulse measurements of Table (4) [19], the concrete mixtures prepared with limestone filler content would be classified as good concrete mixtures.

Table (4):Concrete classification based on ultrasonic pulse velocity [19]

\begin{tabular}{|c|c|}
\hline Pulse velocity $(\mathbf{m} / \mathbf{s})$ & Concrete classification \\
\hline $\mathrm{V}>4500$ & Excellent \\
\hline $4500>\mathrm{V}>3500$ & Good \\
\hline $3500>\mathrm{V}>3000$ & Questionable \\
\hline $3000>\mathrm{V}>2000$ & Poor \\
\hline $\mathrm{V}<2000$ & Very Poor \\
\hline
\end{tabular}

\section{Conclusions}

Based on the results obtained in this study, and within the limitation of the test parameters, the following conclusions can be drawn:

1. Slump decreases with the increase of limestone filler amount, so water demand increases slightly with increasing limestone filler content.

2. The compressive strength of concrete increases with the increase in limestone filler replacement up to an optimal value, concrete made with $20 \%$ limestone filler replacement by sand showed higher compressive strength which increased by $14.6 \%$.

3. Partial replacement of sand by limestone filler increased the splitting tensile strength, which enhanced to become $28 \%$ at $20 \%$ limestone filler replacement then decreased with the increase of limestone filler replacement.

4. With $10 \%$ and $20 \%$ limestone filler addition, ultrasonic pulse velocity values notably increased then decreased with limestone filler amount increase.

\section{References}

1. Topçu, I.B.\& Uğurlu, A., "Effect of the use of mineral filler on the properties of concrete", Cement and Concrete Research, Vol. 33, 2003, pp. 1071-1075.

2. Lothenbach, B., Saout, G., Gallucci, E.\& Scrivener, K.," Influence of limestone on the hydration of Portland cements", Cement and Concrete Research, Vol. 38, 2008, pp. 848-860.

3. Svermova, L., Sonebi, M.\& Bartos, P.J.M., "Influence of mix proportions on rheology of cement grouts containing limestone powder", Cement and Concrete Composites, Vol. 25, 2003, pp. 737-749.

4. Yahia, A., Tanimura, M.\& Shimoyama, Y., " Rheological properties of highly flowable mortar containing limestone filler-effect of powder content and W/C ratio", Cement and Concrete Research, Vol.35, 2005, pp. 532-539. 
5. Voglis, N., Kakali, G., Chaniotakis, E.\& Tsivilis, S., "Portland-limestone cements. Their properties and hydration compared to those of other composite cements", Cement and Concrete Composites, Vol. 27, 2005, pp. 191-196.

6. Celik ,T\& Marar K. ," Effects of crushed stone dust on some properties of concrete", Cement and Concrete Research, Vol.26, 1996, pp.1121-1130.

7. Iraqi Standard Specification No.5 (1984)," Properties of Ordinary Portland Cement", Iraq, 1984.

8. BS 882-1992,"Aggregate from Natural Source for Concrete", British Standard Institution, 1992.

9. ASTM C143-04, "Slump of Hydraulic-Cement Concrete", American Society for Testing and Materials, 2004.

10. ASTM C138-04, "Unit Weight, Yield, and Air Content (Gravimetric) of Concrete1", American Society for Testing and Materials, 2004.

11. BS 1881:part116:1983"Testing of Hardened Concrete", British Standard Institution, 1983.

12. ASTM C496-04, "Splitting Tensile Strength of Cylindrical Concrete Specimens" ,American Society for Testing and Materials, 2004.

13. ASTM C597-04, "Pulse Velocity Through Concrete", American Society for Testing and Materials, 2004.

14. Bonavetti, V., Donza, H, Mene'ndez, G, Cabrera, O\& Irassar, E.F.," Limestone filler cement in low w/c concrete: A rational use of energy", Cement and Concrete Research, Vol. 33 ,2003, pp. 865-871.

15. Benachour, Y., Davy, C.A. , Skoczylas, F.\& Houari, H., " Effect of a high calcite filler addition upon microstructural, mechanical, shrinkage and transport properties of a mortar", Cement and Concrete Research, Vol.38, 2008, pp.727-736.

16. Pera, J., Husson, S.\& Guilhot, B.,"Influence of ground limestone on cement hydratation", Cement and Concrete Composites, Vol. 21, 1999, pp. 99- 105.

17. Jones, R\&, Facaoaru, I, " Recommendation for Testing Concrete by the Ultrasonic Pulse Method", Materiaux Et Construction, Vol. 2, No.10, 1969.

18. Carcańo, R.S.\& Moreno, E.I.," Evaluation of concrete made with crushed limestone aggregate based on ultrasonic pulse velocity", Construction and Building Materials Vol.22, 2008, pp. 1225-1231.

19. Neville, A.M., "Properties of concrete", 3rd ed., Burnt Mill , Harlow, Essex, England ,Longman Scientific \& Technical, 1981.

The work was carried out at the college of Engg. University of Mosul 